\title{
SS-019 大学全入時代のキャリア教育〜ジェンダーの視点からの検討
}

\author{
企画代表者：土肥伊都子 (神戸松蔭女子学院大学) \\ 企画者, 司会者: 永久ひさ子 (文京学院大学) \\ 話題提供者: 大野 祥子 (白百合女子大学) \\ 話題提供者: 若尾 良徳 (日本体育大学) \\ 指定討論者: 安達 智子 (大阪教育大学) \\ 指定討論者: 金井 篤子 (名古屋大学)
}

大学全入時代となり，一言で大学生といえども，生育環境や家庭の社会経済的地位などはますます幅 広く多様になりつつある。そのため, 大学生を一括りに論じることは難しくなり, その学生が置かれた 文脈を考慮したジェンダー教育が必要である。

そこで本シンポジウムでは, 個々の学生がキャリアデザインするにあたって, どのようなジェンダー 教育が効果的であるかについて議論する。すなわち, 企画者がいくつかの学生のモデルケースを設定し, それらのケースに対して, どのようなことを学生に考えさせるのがよいか, 具体的な教育方針や実践さ れている教育方法などについて検討する。そしてそれらについて, 指定討論者がコメントし, フロアも 交えてさらに掘り下げて討論する。

第 1 日 9 月11日 (水) $13: 20 \sim 15: 20$

A 棟 2 階 /第14会場 AN222

\section{SS-020 スポーツの眼, ロボットの眼, 武術の眼（2）一視点の行き場・ 置き場が動作の成否を決める?}

\author{
企画代表者, 司会者: 佐々木正晴 (弘前学院大学) \\ 話題提供者: 佐藤 佑介 (日本大学) \\ 話題提供者: 丹沢勉\# (山梨大学) \\ 話題提供者: 下田 雄二\# (北東北無形文化遺産実践研究協会) \\ 指定討論者：鳥居 修晃 (東京大学)
}

身体の各部位／全体の活動・動作一たとえば，跳ぶ，歩く，動きをかわす一を展開する途上で，事物・ 事象を捉える視覚認知系の活動は, 動きを止めて対象を捉える場合の活動と同日には論じられない。前 年度シンポジウムにおいて, 心理学の分野では通常とりあげられないスポーッ, ロボット, 武術という 3 種の領域から研究報告を承け, 視覚認知活動と身体操作との関連性について探索した。このとき, 視 点の行き場・置き場が動作の成否を決めるのではないか, という疑問が生じた。今回のシンポジウムに おいて, 改めて, スポーツ, ロボット, 武術の 3 領域における視点の行き場・置き場に応じた失敗例と 成功例とを突き合わせ，その検証を図る。同時に，開眼者および脳損傷者における長期に亘る視覚・触 覚系の認知活動の形成過程を追求した成果を踏まえ, 近空間一遠空間を主軸とする視空間の構造化の観 点を加えて, 総合的に議論を進めたい。 